\title{
ELECTRICITY GENERATED BY ALTERNATIVE BIOFUEL PRODUCTED FROM AGRICULTURAL WASTE
}

\author{
Sehsah, E. M. E.*
}

\begin{abstract}
Egypt still depends largely on petrol and diesel to run internal combustion engines with its attendant problems of scarcity, pollution of the environment, and contribution to global warming, and cost. The aim of the current research is the ability to apply the biofuel produced from agriculture waste bioethanol and biogas to generate the electricity by operating the two stroke Gasoline Generator. The bio-ethanol produced from the potato's wests in 2014, Faculty of agriculture, Kafrelsheikh University was mixed with Gasoline fuel to obtain the three different percentage 0\%, $20 \%$ and 50\%. As well as the study included that the ability to produce the biogas. The biogas production unit consists of main reactor tank from plastic with capacity $1000 \mathrm{~L}$ fixed at ground and the collecting gas tank put into the top of main reactor tank. The gasoline with octane 80 was used as a control fuel at two different throttle fuel positions. The main treatment were the two bioethanol fuel E20 (20\%) and E50 (50\%) to test at half and full open throttle valve compared to application of biogas to generate the electricity at full open fuel throttle valve. Bachrach Fylite Insight Plus @ model 374 analyzer is used to measure the exhaust gases. This current research will discuss the potentials, obstacles and necessary framework conditions for the utilization of biogas for small scale electricity generation in Egypt. The results showed that the bioethanol and biogas may able to operate two stroke SI engine. It is clearly that, the electrical energy decreases when the ethanol was added to the Gasoline fuel Oct. Nr. 80 at full and half throttle position. The electrical power for gasoline Oct.Nr.80 fuel was $720 W$ compared to $680 \mathrm{~W}, 540 \mathrm{~W}$ and $320 \mathrm{~W}$ for E20 and E50 bioethanol fuel and biogas respectively at full throttle position. Also the maximum electrical power generated from biogas was $332.6 \mathrm{~W}$ for around 57 min operating time/day.
\end{abstract}

\footnotetext{
* Associate Prof., Dept. of Agric. Eng., Fac. of Agriculture, Kafrelsheikh Univ.33516, Egypt, sehsah_2000@yahoo.de
} 
The percentage of the $\mathrm{CO}_{2}$ in exhaust gases were $9.1 \%, 7.3 \%, 5.9 \%$ and $4.2 \%$ for gasoline Oct.Nr.80 fuel, bioethanol E20, E50 and biogas respectively at full throttle position. The biogas may be reducing the exhaust gases emissions of the $\mathrm{CO}$ and $\mathrm{CO}_{2}$ compared with the Gasoline fuel and bioethanol E20, E50 blend fuel.

Keywords: Electricity, Biofuels, Biogas, exhaust emissions.

\section{OBJECTIVES}

The aim of the present research is the ability to apply the bio-ethanol and biogas to produce the electricity by operating the two

stroke Gasoline engine Generator. As well as, analysis the exhaust gases emission during application of the bioethanol and biogas fuel that produced from agricultural waste crops to operate the two stroke Gasoline generator -engine. The aim goes also to measure the exhaust gases emission of Gasoline electric generator under different blend bioethanol fuel with Gasoline fuel under laboratory conditions and noise test.

\section{INTRODUCTION}

$\mathrm{T}$ The total energy consumption grew from 4,675 to 8,286 million tons of oil equivalent between 1973 and 2007 (IEA, 2009). With the prediction by the United Nations showing that by 2050 the earth's population will be around 9 billion people, an approximate 30\% increase, there will only be an upward trend on the global demand for energy (Kibert, 2008). Mabee, (2007) showed that Brazilian gasoline has a legal alcohol content requirement ranging from $20-25 \%$ according to renewable fuel standards. Most vehicles are being run on E20 or E22, but sales of flex-fuel vehicles capable of operating on E85 blends are strong. Baiju et al. (2009) used methyl and ethyl ester of Karanja oil to run CI engine. They observed good engine performance with reduced emissions of HC (hydrucarbon) and smoke. Farrell et al., (2006), Granda Cesar et al., (2007), Kim and Dale, (2005) showed that the "greenness" of a biofuel like ethanol is therefore highly dependent upon the efficiency of all stages in the process from raw material to the end use of product and its avoided use of fossil fuels. While corn ethanol is claimed to have negative energy content or slightly positive value, environmental benefits of cellulosic ethanol cannot be refuted as the corresponding estimated net energy is 
rather high (Solomon2007). The alcohols such as methanol $\left(\mathrm{CH}_{3} \mathrm{OH}\right)$, ethanol $\left(\mathrm{C}_{2} \mathrm{H}_{5} \mathrm{OH}\right)$, propanol $\left(\mathrm{C}_{3} \mathrm{H}_{7} \mathrm{OH}\right)$, and butanol $\left(\mathrm{C}_{4} \mathrm{H}_{9} \mathrm{OH}\right)$ can be used as alternate motor fuels. The combustion heats of alcohols are lower than those of hydrocarbons due to higher oxygen contents. Practically, any of the organic molecules of the alcohol family can be used as a fuel (Demirbas 2005). However, only methanol and ethanol fuels are technically and economically suitable for internal combustion engines (ICEs). Carbon monoxide $\mathrm{CO}$, Carbon dioxide $\mathrm{CO}_{2}$ and Hydrocarbon $\mathrm{HC}$ emissions also decrease when using a methanol-gasoline blend Pankhaniya et al (2011). Sehsah et., at. (2014) studied the bioethanol as alternative fuel for farm machine. They showed that it may able to apply the bioethanol as an alternative fuel in farm machine such as the engine of the sprayer. The lower values of break horse power of the engine were 4.5 $\mathrm{KW}, 6.3 \mathrm{KW}$ and $6.9 \mathrm{KW}$ for the fuel blend E60 with load at first, second and third fuel throttle position respectively. On the other hand, the fuel blend E10 and E30 gave no significant different compared with the gasoline Octane 80 fuel on the effect of the break horse power under all treatment conditions. The fuel blend E10 and E30 gave no significant different compared with the gasoline Octane 80 fuel on the effect of the rotational speed under all treatment conditions. Because ethanol or ethylic alcohol $\left(\mathrm{C}_{2} \mathrm{H}_{5} \mathrm{OH}\right)$ can be produced from herbaceous seeds, beets and potatoes, it can be a suitable alternative fuel for oil categories fuels (Demirbas, 2008A and Michaelides 2012). Ethanol has blended to gasoline for increasing octane number and its non-detonation properties. (Eyidogan et al.2010) investigated the effect of ethanol-gasoline (E5, E10) and methanol-gasoline (M5, M10) fuel blends on the performance and combustion characteristics of a SI engine. They showed using ethanol lead to an increase in BSFC and octane number. These results were expected because the heating values of the alcoholsare $37 \%-53 \%$ lower than that of pure gasoline. (Li et al. 2005) used ethanol fuel, which benefits from a low Cetin number, in a two stroke diesel engine with exhaust gas recirculation (EGR).They showed ethanol makes lower soot and $\mathrm{NO}_{\mathrm{X}}$, and also causes $2 \%-3 \%$ increase in thermal efficiency. The effects of ethanol addition (10\% and15\% in volume) on the performance and emissions of a four cylinder turbocharged indirect injection diesel 
engine having different fuel injection pressures (150, 200 and 250 bar) at full load were investigated by Can et al. (2004). Their results showed that the ethanol addition reduces $\mathrm{CO}$, soot and $\mathrm{SO}_{2}$ emissions, although hit caused an increase in $\mathrm{NO}_{\mathrm{X}}$ emission and approximately $12.5 \%$ (for $10 \%$ ethanol addition) and 20\% (for $15 \%$ ethanol addition) power reductions. Zhai et al., (2007) and (Lee, et al. 2010) indicated that the ratio of the heating value for one liter of fuel gasoline versus E10 is 1.02. The theoretical mass-based ratio of fuel use for an equivalent amount of energy is 1.1 for E10 versus gasoline. For the same amount of energy released from E10 and gasoline, the theoretical ratio of $\mathrm{CO}_{2}$ emissions for E85 versus gasoline is 0.98. Biogas is a mixture of methane, carbon dioxide, water and hydrogen sulphide produced during the anaerobic decomposition of organic matter. Biogas can be recovered and used either directly for cooking, lighting or it can be transformed in any kind of thermal, electrical or mechanical energy. It can also be compressed, much like natural gas, and used to power motor vehicles. Methane is the valuable component under the aspect of using biogas fuel. The calorific value of biogas is about $6 \mathrm{kWh} / \mathrm{m}^{3}$, it is corresponds to about half a liter of diesel oil. Biogas consists mostly of methane $\left(\mathrm{CH}_{4}\right.$, around $\left.65-70 \%\right)$ carbon dioxide $\left(\mathrm{CO}_{2}\right.$, around 25-30\%) and varying quantities of water $\left(\mathrm{H}_{2} \mathrm{O}\right)$ and hydrogen supplied $\left(\mathrm{H}_{2} \mathrm{~S}\right)$ and some trace amounts of other compounds, which can be found, especially in waste dump biogas (e.g. ammonia, $\mathrm{NH}_{3}$, hydrogen $\mathrm{H}_{2}$, nitrogen $\mathrm{N}_{2}$, and carbon monoxide, $\mathrm{CO}$ ). The amount of each gas in the mixture depends on many factors such as the type of digester and the kind of organic matter. Diverse sludge composition requires diverse/specialized reactor designs to achieve a high conversion (GTZ,2010). In Germany and other industrialized countries, power generation is the main purpose of biogas plants; conversion of biogas to electricity has become a standard technology. Theoretically, biogas can be converted directly into electricity using a fuel cell. However, very clean gas and expensive fuel cells are necessary for this process. This is therefore still a matter for research and is currently not a practical option. Biogas can be used as fuel in nearly all types of combustion engines, such as gas engines (Otto motor), diesel engines, gas turbines and sterling motors etc (GTZ,2010). Small biogas turbines with 
power outputs of $30-75 \mathrm{~kW}$ are available on the market, but are rarely used for small-scale applications in developing countries as they are expensive. In most commercially run biogas power plants today, internal combustion motors have become the standard technology either as gas or diesel motors (Yasar et al 2014). The useful part of the energy of biogas is the calorific value of its $\mathrm{CH}_{4}$ content. The other components have strictly speaking energy content also but they do not participate in a combustion process. Instead of contributing they rather absorb energy from the combustion of $\mathrm{CH}_{4}$ as they usually leave a process at a higher temperature (exhaust) than the one they had before the process (mainly ambient temperature). Biogas, on the other hand has been widely used in certain countries for generating heat and electricity (Deublein and Steinhauser, 2008). Nonetheless, due to its low calorific value resulting from the high proportion of carbon dioxide present, CI engines fuelled with biogas suffer from low engine thermal efficiency and high unburned hydrocarbons in exhaust emissions, especially at part load operations (Kobayashi et al., 2007). Fuel upgrading measures have been recommended for biogas to be used as a fuel source for CI engines (Jönsson, 2004) but these upgrading techniques require external energy input (i.e. approximately 3-6\% of biogas energy output), hence decreasing the overall energy efficiency of biogas.

\section{MATRIAL AND METHODS}

Two different laboratory systems of bioethanol and biogas production were constructed in the laboratory of Agriculture Engineering Department, Faculty of Agriculture, Kafrelsheikh University, Egypt to produce the electricity from bioethanol and biogas.

Bioethanol unit: The reactor was manufactured in the laboratory of Agricultural Engineering Department, Kafr El Sheikh University (Sehsah et al.,2015). The dimensions of reactor were $28 \mathrm{~cm}$ diameter and $55 \mathrm{~cm}$ height that correspond $6 \mathrm{~L}$. The cover of the reactor was made of a circuitous stainless steel with thickness of $1 \mathrm{~mm}$. The cover of the reactor equipped with a hole as the outlet of the ethanol liquid. A rubber gasket was fitted between the cover and the vessel to provide an ethanol. However the system was isolated by Wool thermal with $30 \mathrm{~mm}$ thickness. 
One bacterial strain (Bacillus subtilis (E34) as amylolytic bacteria) was obtained from prof. Dr. Elsayed B. Belal professor of agricultural microbiology, Dep. of Agric. Botany, Fac. of Agriculture, Kafrelsheikh University and these bacterial strains was isolated. B. subtilis (E34) was cultivated in nutrient liquid medium. $250 \mathrm{ml}$ nutrient liquid medium was inoculated with $2 \mathrm{ml}$ of a cell suspension of B. subtilis (E34) (nutrient broth medium, $108 \mathrm{cfu} / \mathrm{ml}$ ) was incubated at $30^{\circ} \mathrm{C}$ and $150 \mathrm{rpm}$ for 3 days. The cultures were incubated at $30^{\circ} \mathrm{C}$ and $150 \mathrm{rpm}$ for 3 days. Thereafter, $250 \mathrm{ml}$ from bacterial strain culture $(108 \mathrm{cfu} / \mathrm{ml})$ was applied on aqueous pretreated potato wastes $(1 \mathrm{~kg}$ of crushed potato wastes: 9 liters of water for 7 days under room temperature $\left(28{ }^{\circ} \mathrm{C}\right)$ in reactor. The unit test of bioethanol consisted of the gasoline spark ignition Generator model Einhell made in Germany. The Generator $800 \mathrm{~W}$ was used to evaluate the bio-ethanol blend fuel that produced from the potato wastes (Sehsah et al, 2014). As well as, test the smoke gas was analyzed during the operation of the Generator at different ratios' of Bio-ethanol blend. The Fylite Insight Plus R model 374 made in Germany was used to analyze and measure the exhaust gases at three different blends of bioethanol 0\%,20\% and 50\% bio-ethanol as shown in figure 1 .

Biogas production unit: Biogas production unit consists of main reactor tank from plastic with capacity $1000 \mathrm{~L}$ fixed at ground and the collecting gas tank with $1000 \mathrm{~L}$ put into the main reactor tank as shown in figure 2. The inlet PVC tube fixed at the height $10 \mathrm{~cm}$ from the bottom in main reactor tank. In the other side of main reactor process tank, the outlet PVC tube set at $r 0 \mathrm{~cm}$ from the top. The animal dairy wastes were prepared, collected and stored weekly from the animal farm in faculty of agriculture, Kafrelsheikh University. Biogas was produced using cow dung seeded with rice husk as feedstock in a plastic digester. The 200 liters of the animal slurry was inlet into the reactor. The feeding daily rate was $3 \mathrm{~kg}$ as total sold from the dairy wastes. After 3 days the biogas starting to produce and the gas collector tank raised up to the main process reactor tank. The production of biogas unit was constructed in the glass greenhouse to obtain the thermo-phallic biogas conditions with 55 degree in summer season. The animal slurry waste was agitated by using the mechanical agitator before feeding into the reactor for 10 minutes. As 
well as, the potassium hydroxide $(\mathrm{KOH})$ with $30 \%$ concentration was used to remove the carbon dioxide $\left(\mathrm{CO}_{2}\right)$ from the produced biogas. The $500 \mathrm{ml}$ flask potassium hydroxide $\mathrm{KOH}$ with $30 \%$ used to remove the $\mathrm{CO}_{2}$ during application of biogas to operate the engine-generator Einhell $800 \mathrm{~S}$ as shown in Figure 2. The solution of $\mathrm{KOH}$ flask was constructed into the line of biogas produced between the collected biogas tank and the Einhell 800S Generator. The weather station model WS2300 and Data logger Model fixed into the glass greenhouse beside the biogas production unit. The compressed fuel air ratio was adjusted at 8.2:1 by change the head cylinder chamber in the Einhell 800S Generator.

\section{Procedures}

The bio-ethanol produced from the potato's wests in 2014, Faculty of agriculture, Kafrelsheikh University was mixed with

Gasoline fuel in three different percentage $0 \%, 20 \%$ and $50 \%$. To obtain the different ratios of bio-fuel E20 and E50, The 20\% ethanol mixed with $80 \%$ Gasoline fuel Octane Nr. 80 and 50\% ethanol mixed with 50\% Gasoline fuel Octane Nr. 80 respectively. The fuel throttle valve was adjusted at the proper position of the engine to obtain two different positions (half and full open throttle valve). The gasoline with octane 80 was used as a control fuel at two different throttle fuel positions. Also, the biogas prepared to apply in the gasoline generator for only full throttle fuel position. The ethanol mass flow rate is measured by a graduated cylinder. Exhaust gas recirculation (EG) is one of the most widely used methods of controlling emissions, particularly nitrogen oxide ( $\left.\mathrm{NO}_{\mathrm{X}}\right), \mathrm{CO}$, $\mathrm{CO}_{2}$, and $\mathrm{HC}$ (hydrocarbons). The exhaust emissions of $\mathrm{CO}_{2}$ and $\mathrm{CO}$ from the test generator engine are measured and analyzed.

The engine has a compression ratio of $9.3: 1$, a rated power of $800 \mathrm{~W}$ at $3000 \mathrm{rpm}$. The multi-meter MR445 with PC used to measure the temperature and electricity power and energy produced during the operating of Einhell 800S Generator by using the gasoline, two bioethanol blend ratios and biogas. The bio-ethanol is injected by the original engine Gasoline injectors, so that ethanol and Gasoline fuel Octane Nr. 80 can be mixed in the intake ports online by using two external tanks and two ways valve. The Bachrach Fylite Insight plus R model 374 made in Germany analyzer is used to measure exhaust gases .It is a small and light weight $(800 \mathrm{~g})$ 
analyzer. Its response time is $15 \mathrm{~s}$ and flow rate approximate $1.21 / \mathrm{min}$. This analyzer can measure Carbon monoxide (CO) with ppm, Carbon dioxide $\left(\mathrm{CO}_{2}\right)$ percentage, Hydrocarbons $(\mathrm{HC})$ with ppm, Oxygen $\left(\mathrm{O}_{2}\right)$ percent and Nitric oxide $\left(\mathrm{NO}_{\mathrm{X}}\right)$. The excess air (lambda) can also be determined by this analyzer. Using lambda and stoichiometric air to fuel ratio, it may able to calculate the actual air to fuel ratio.

Table 1 Technical features of the SI engine Einhell 800S Gasoline Generator

\begin{tabular}{ll}
\hline Technical data & Description \\
\hline Model & Einhell STE800/1 \\
Functioning cycle & 2-strokes engine -air cooled \\
Number of cylinders & 1 \\
Type & Vertical, in-line \\
Displacement & $63 \mathrm{~cm}^{3}$ \\
Max. motor power & $0.95 \mathrm{~kW}$ \\
Sound power level & $92 \mathrm{~dB}(\mathrm{~A})$ \\
Voltage/Ampere & $230 \mathrm{~V} / 2.8 \mathrm{~A}$ \\
Compression ratio & $9.3: 1$ \\
Frequency & $50 \mathrm{~Hz}$ \\
Speed regulation & Electronic \\
\hline
\end{tabular}

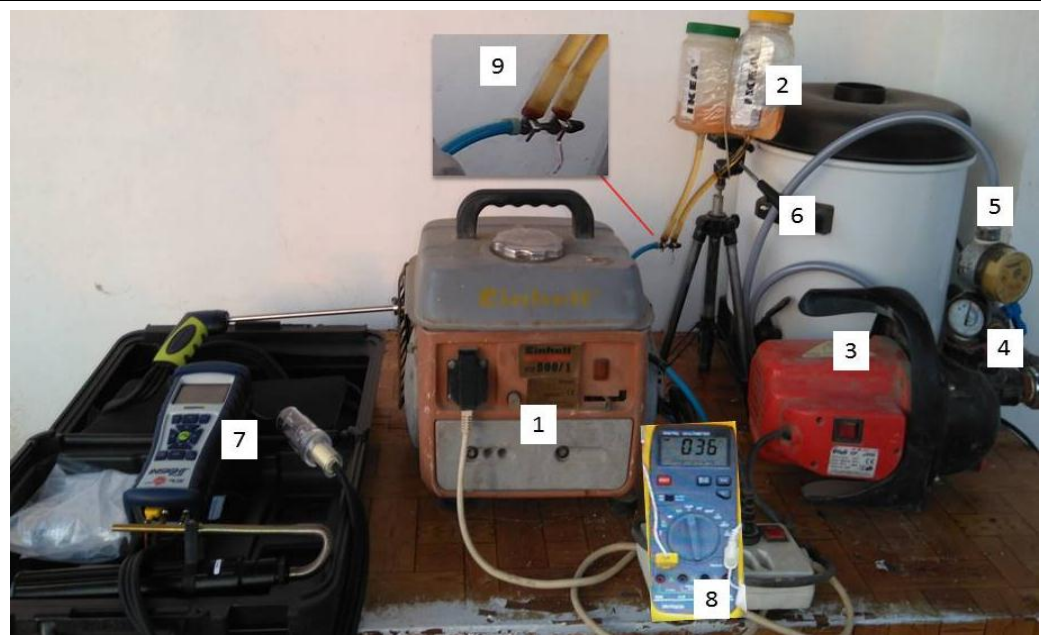

1-Einhell800S two stroke SI. Generator 2-Two external tank for bioethanol and Gasoline fuels 3Water pump as load 4-Pressure gauge manometer 5-Flow meter 6- Water tank 20 7-Bachrach gas analyzer 8-Multimeter MR445 9-Three way valves to obtain the blend fuel ratios

Figure 1: Bioethanol experimental set to generate the electrical power during application of the blend ratios of bioethanol in two stroke gasoline generator. 


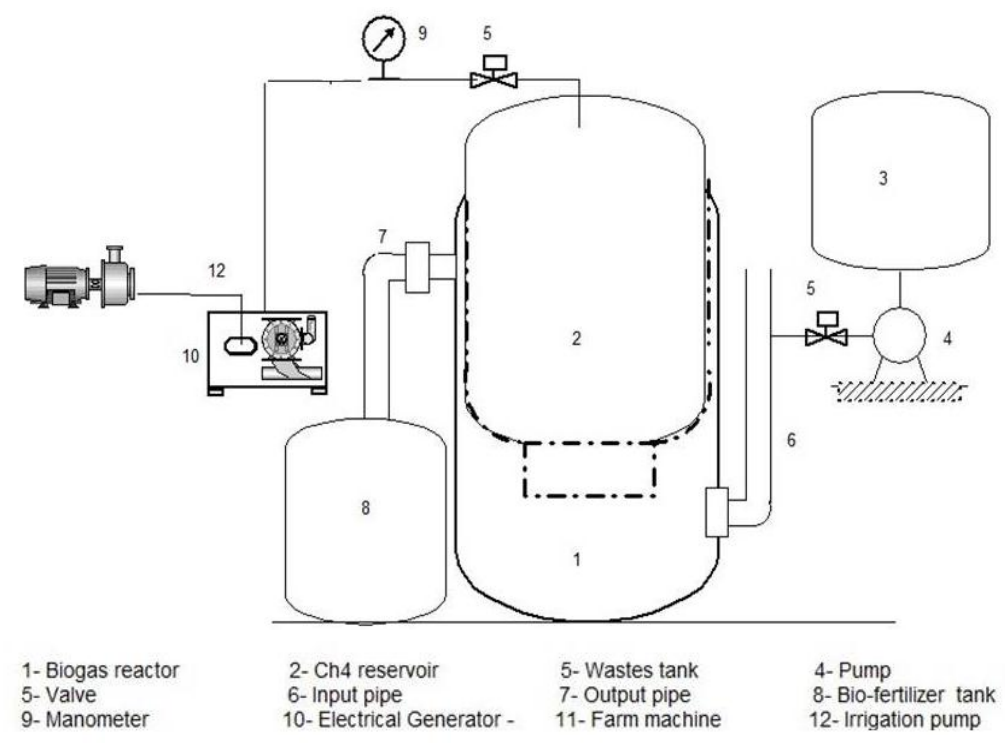

Figure 2: Biogas production unit and their component experimental set.

\section{RESULTS AND DISCUSSION}

The results illustrated that the bioethanol and biogas may able to apply in two stroke gasoline engine. Figure 3 indicate the effect of fuel mixing ratios; throttle position on the energy production by two stroke gasoline engine from different bioethanol blend ratios and biogas. It is clearly that, the electrical energy decreases when the ethanol was added to the Gasoline fuel Oct. Nr. 80 at two throttle position. However, the highest values of electrical power for gasoline Oct.Nr.80 fuel was $720 \mathrm{~W}$ compared to $680 \mathrm{~W}, 540 \mathrm{~W}$ and $320 \mathrm{~W}$ for bioethanol E20, E50 and biogas respectively at full throttle position. As well as, the highest values of electrical energy for gasoline Oct.Nr.80 fuel was $350 \mathrm{~W}$ compared to $300 \mathrm{~W}$, and $220 \mathrm{~W}$ for bioethanol E20, and E50 respectively at half throttle position. This result may be due to the low heat calorific value of the blend bioethanol and biogas compared to the highest calorific value of Gasoline Octane No.80 fuel. Table 2 and figure 4 indicate the electrical power and energy generated from the biogas during the biogas production and their operating time. The electrical energy may be produced from the biogas that applied as fuel in two stroke gasoline engine. It was not able to measure the concentration of methane in biogas production. The volume of biogas in collecting gas tank was estimated by measuring the 
height of the collector gas tank and their circumference. The maximum generated electrical power was $332.6 \mathrm{~W}$ for around 57 min operating time from $8 \leqslant 0 \mathrm{~L}$ total biogas volume production (methane $+\mathrm{Co}_{2}$ and other gases) during first day. Also, the minimum value of generated electrical power was $293.5 \mathrm{~W}$ for around 46 min operating time from $5^{9} 0 \mathrm{~L}$ total biogas volume production (methane+ $\mathrm{Co}_{2}$ and other gases) during 5 day. The decrease of the generated electrical power may be due to decrease the total biogas volume production (methane $+\mathrm{Co}_{2}$ and other gases) every day. Also, maximum generated electrical energy was $0.3 r \mathrm{KW} h$ for around 57 min operating time from $8 \leqslant 0 \mathrm{~L}$ total biogas volume production (methane $+\mathrm{Co}_{2}$ and other gases) during first day. Also, the minimum value of generated electrical energy was $0.2 \mathrm{KW}$ h for around $46 \mathrm{~min}$ operating time from $5^{9} 0 \mathrm{~L}$ total biogas volume production (methane+Co and other gases) during day. The decrease of the generated electrical power may be due to decrease the total biogas volume production (methane $+\mathrm{Co}_{2}$ and other gases) every day.

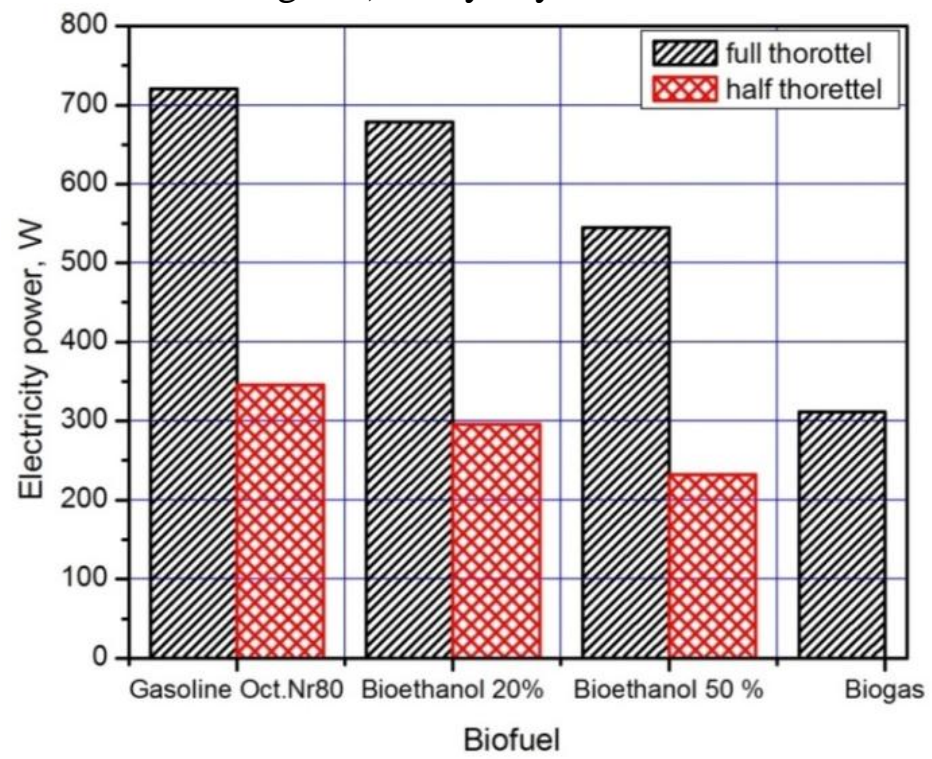

Figure 3: Present the electrical power generated from different biofuel during the operating of electrical generator.

Figure 4 illustrate the electrical energy produced from biogas during the operating of electrical generator. The electrical energy affected due to decrease of the volume of daily biogas production. At first day it could be 
obtain of the maximum electrical energy from biogas and the trend go to decrease due to decrease of the fermentation in the batch biogas reactor. It may able to obtain the constant generated electrical energy when used an agitator in the reactor but it need also power to operate the agitator. This result could be researching as further investigation.

Table 2: Display the electrical power and energy generated from biogas

\begin{tabular}{ccccc}
\hline $\begin{array}{c}\text { Elapsed time } \\
\text { for biogas } \\
\text { produced, day }\end{array}$ & $\begin{array}{c}\text { Electrica } \\
\text { 1 Energy, } \\
\text { KW.h }\end{array}$ & $\begin{array}{c}\text { Electrical } \\
\text { Power, } \\
\text { W }\end{array}$ & $\begin{array}{c}\text { Consumed } \\
\text { operating time, } \\
\text { min }\end{array}$ & $\begin{array}{c}\text { Total biogas } \\
\text { volume, L }\end{array}$ \\
\hline 1 & $\mathbf{0 . 3 2}$ & $\mathbf{3 3 2 . 6}$ & $\mathbf{5 7}$ & $\mathbf{8 4 0}$ \\
2 & 0.29 & 327.2 & 53 & 765 \\
3 & 0.24 & 297.6 & 49 & 659 \\
4 & 0.24 & 303.8 & 47 & 610 \\
5 & $\mathbf{0 . 2 3}$ & $\mathbf{2 9 3 . 5}$ & $\mathbf{4 6}$ & $\mathbf{5 9 0}$ \\
6 & 0.29 & 322.2 & 54 & 790 \\
7 & 0.27 & 320.4 & 50 & 689 \\
8 & 0.28 & 319.6 & 52 & 730 \\
9 & 0.25 & 307.5 & 48 & 670 \\
10 & 0.23 & 293.6 & 47 & 600 \\
\hline
\end{tabular}

\section{Analysis of exhaust gases emission produced from biofuels}

The addition of bioethanol to gasoline fuel tends to reduce the emission of exhaust gases. This result was argument with Pankhaniya et al (2011) and Can et al (2004). The increasing of blend ethanol ratios tends to reduce the $\mathrm{CO}$ concentration with ppm and $\mathrm{CO}_{2}$ percentage as shown in figures 5 and 6. The ethanol E50 gave low values of CO gas compared to Gasoline Oct.No.80 fuel as shown in figure 5. The concentrations of the $\mathrm{CO}$ gases were $1407 \mathrm{ppm}, 1173 \mathrm{ppm}, 554 \mathrm{ppm}$ and $260 \mathrm{ppm}$ for gasoline Oct.Nr.80 fuel, bioethanol E20, E50 and biogas respectively at full throttle position. The ethanol E50 gave low values of $\mathrm{CO}_{2}$ gas percentage compared to Gasoline Oct.No.80 fuel as shown in figure 6. The percentage of the $\mathrm{CO}_{2}$ in exhaust gases were $9.1 \%, 7.3 \%, 5.9 \%$ and $4.2 \%$ for gasoline 
Oct.Nr.80 fuel, bioethanol E20, E50 and biogas respectively at full throttle position. The biogas may be reducing the exhaust gases emissions of the $\mathrm{CO}$ and $\mathrm{CO}_{2}$ compared with the Gasoline fuel and bioethanol E20, E50 blend fuel.

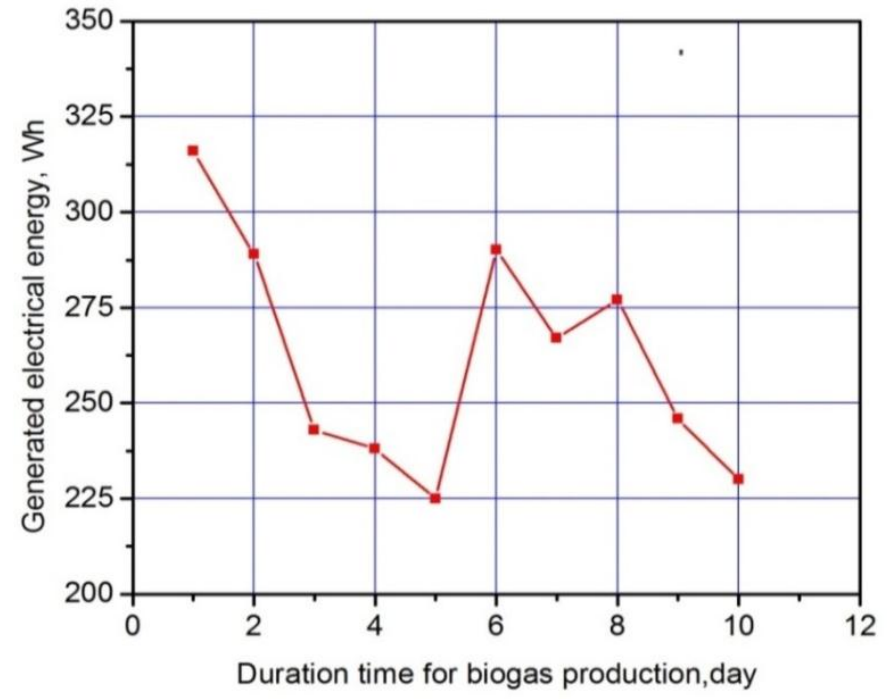

Figure 4: The electrical energy produced from biogas during the operating of electrical generator at full throttle fuel position.

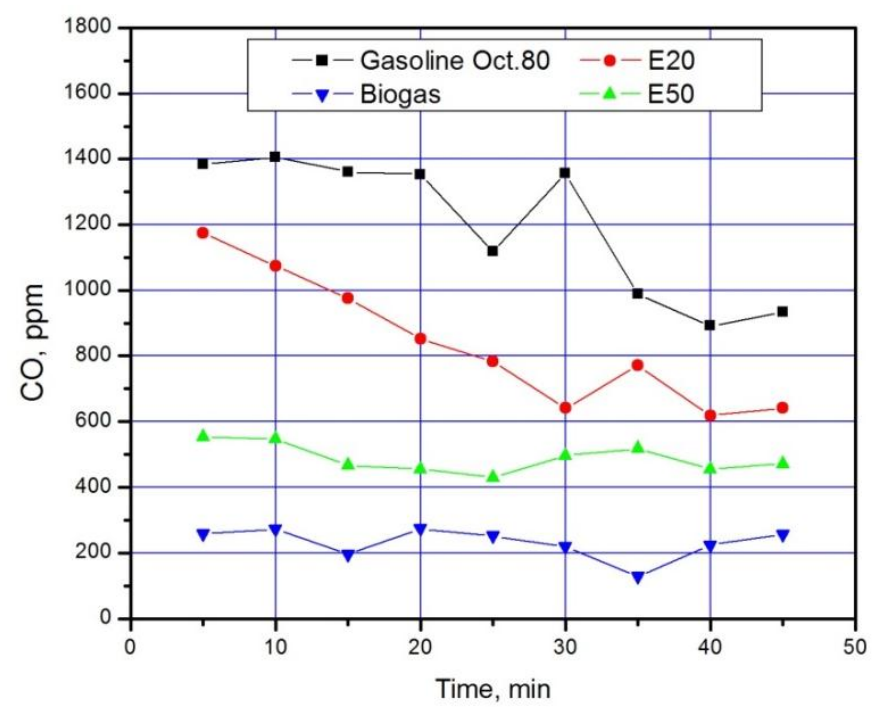

Figure 5: Concentration of $\mathrm{CO}$ produced from different biofuels during the operating of electrical generator at full throttle fuel position. 


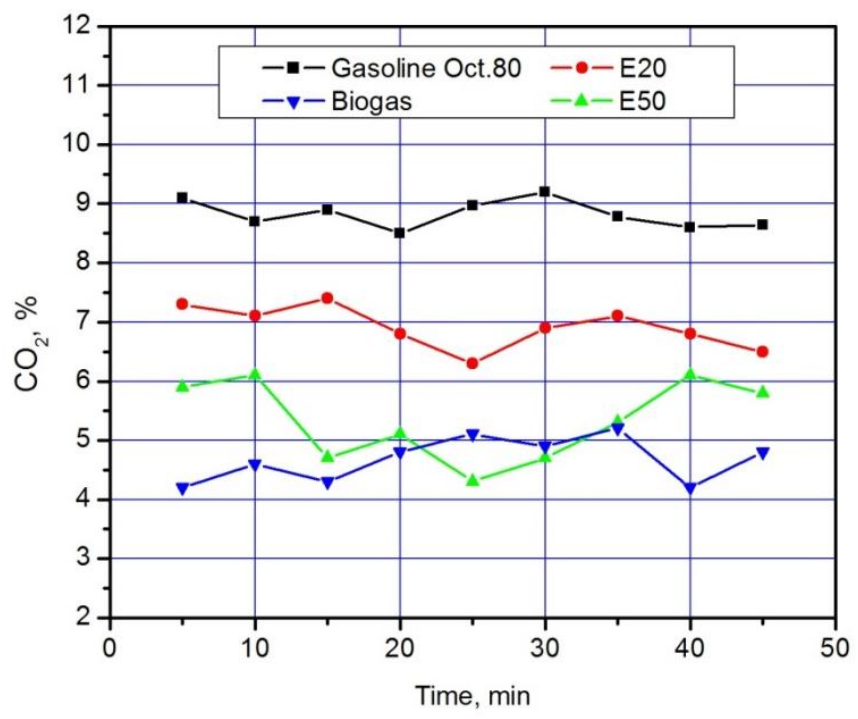

Figure 6: Concentration of $\mathrm{CO}_{2}$ produced from different biofuels during the operating of electrical generator at full throttle fuel position.

In figures 7 and 8, the increasing of blend ethanol ratios tends to reduce the $\mathrm{HC}$ (hydrocarbon) concentration with $\mathrm{ppm}$ and $\mathrm{NO}_{\mathrm{x}}$ gases. The ethanol E50 gave low values of $\mathrm{HC}$ ( hydrocarbon gases) compared to Gasoline Oct.No.80 fuel as shown in figure 6. The concentrations of the HC (hydrocarbons) in exhaust gases were $5122 \mathrm{ppm}, 4170 \mathrm{ppm}, 3283$ ppm and 2441 ppm for gasoline Oct.Nr.80 fuel, bioethanol E20, E50 and biogas respectively at full throttle position. The ethanol E50 gave low values of $\mathrm{NO}_{\mathrm{x}}$ gas percentage compared to Gasoline Oct.No.80 fuel as shown in figure 7 . The percentage of the $\mathrm{NO}_{\mathrm{x}}$ in exhaust gases were 126 ppm, 56 ppm, 46 ppm and 17 ppm for gasoline Oct.Nr.80 fuel, bioethanol E20, E50 and biogas respectively at full throttle position. The biogas may be reducing the exhaust gases emissions for both the $\mathrm{HC}$ and $\mathrm{NO}_{\mathrm{x}}$ compared with the Gasoline fuel and bioethanol E20, E50 blend fuel.

\section{SUMMARY AND CONCLUSIONS}

As an automotive fuel, hydrous ethanol can be used as a substitute for Gasoline in dedicated engines. The result summarized that the bioethanol blend E20 and E50 and biogas fuel may be able to operate the Gasoline electrical Generator integrated with two stroke SI engine. 


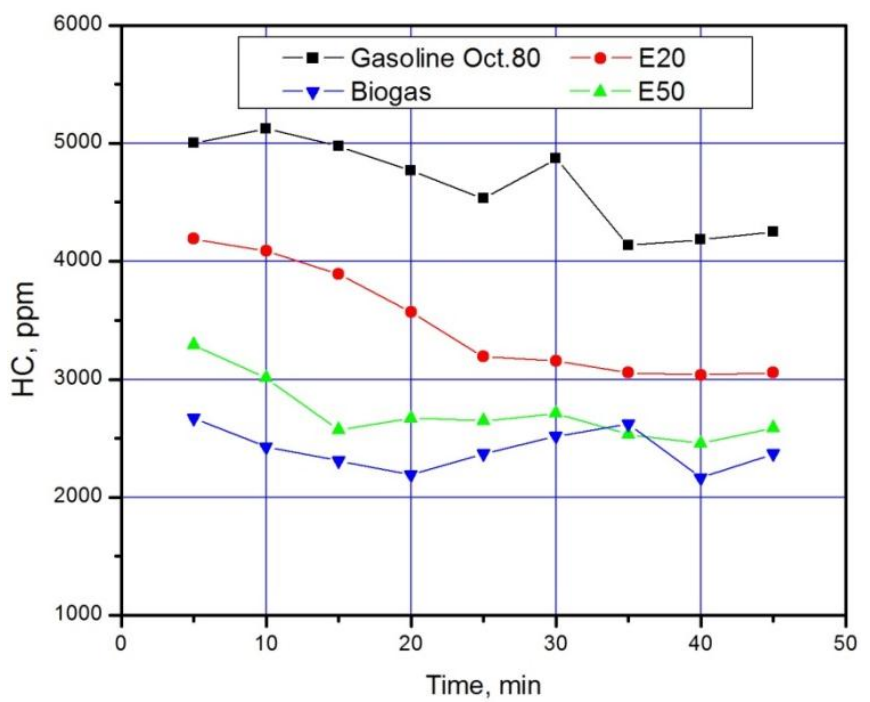

Figure 7: Concentration of $\mathrm{HC}$ (hydrocarbon gases) produced from different biofuels during the operating of electrical generator at full throttle fuel position.

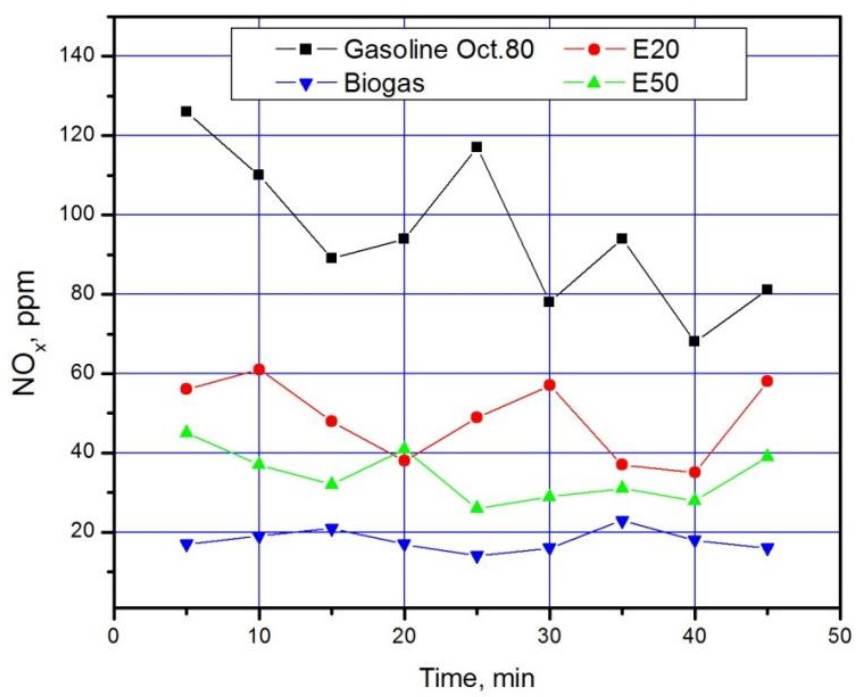

Figure 8: Concentration of $\mathrm{NO}_{\mathrm{x}}$ produced from different biofuels during the operating of electrical generator at full throttle fuel position.

The addition of ethanol tends to reduce the exhaust gases. Also, the biogas may able to generate the electrical energy after changing the compressed air ratios. The addition of the bioethanol gave the low 
generated electrical energy compared to the Gasoline Oct.Nr.80 fuel. Therefore the Gasoline fuel has highest heat calorific value. The $\mathrm{CO}_{2}$ percentage in exhaust gases were 9.1 for gasoline Oct.Nr.80 fuel \%, compared to $7.3 \%, 5.9 \%$ and $4.2 \%$, bioethanol E20, E50 and biogas respectively at full throttle position.

\section{REFERENCES}

Baiju, B., M. K Naik, and L. M. Das. (2009). A comparative evaluation of compression ignition characteristics using methyl and ethyl esters of karanja oil. Renewable Energy 34(6): 1616-1621.

Can O., I. Celikten, and N.Usta, (2004) Effects of ethanol addition on performance and emissions of a turbocharged indirect injection diesel engine running at different injection pressures, Energy Conversion and Management 45 (15)-162429-2440.

Demirbas, A. (2005). Bioethanol from cellulosic materials: A renewable motor fuel from biomass. Energy Sources 27:327-337.

Demirbas, A. (2008A) Realistic Fuel Alternative for Diesel Engines, Springer, London.

Deublein, D., A. Steinhauser (2008) Biogas from Waste and Renewable Resources: An Introduction, Wiley-VCH.

Eyidogan, M. A.N. Ozsezen, M. Canakci, and A. Turkcan (2010) Impact of alcohol-gasoline fuel blends on the performance and combustion characteristics of an SI engine, Fuel 89(10) 2713-2720.

Fachagentur Nachwachsende Rohstoffe e.V. (FNR) (2009) Biogas Basisdaten Deutschland - Stand: Oktober 2008. 7p. Very short but comprehensive overview of the biogas situation in Germany. http://www.fnr-server.de/ftp/pdf/literatur/pdf_185basisdaten_biogas_2009.pdf

Farrell, A. E., (2006). Ethanol can contribute to energy and environmental goals. Science 311: 506-508.

Granda Cesar B., (2007) Sustainable liquid biofuels and their environmental impact. Environmental Progress 26: 233-250.

GTZ (2010): Agro-Industrial Biogas in Kenya - Potentials, Estimates for Tariffs, Policy and Business Recommendations. Study of Deutsches Biomasse Forschungs Zentrum (DBFZ) on behalf of GTZ, Renewable Energy Project Development Programme East Africa. 69 
p. http://www.gtz.de/de/dokumente/gtz2009-en-biogas-assessmentkenya.pdf

IEA, International Energy Agency. 2009. Key World Energy Statistics 2009. Paris.

IEA. (1999). Automotive fuels for the future. The Search for Alternatives. Inter National Energy Agency.

Joenson, O., M. Persson, M. Seifert, (2007) European Experience of Upgrading Biogas to Vehicle Fuel and for Gas Grid Injection. In: Proceedings of $15^{\text {th }}$ European Biomass Conference \& Exhibition, 2007 Berlin, Germany.

Kibert, C. J. (2008) Sustainable Construction: Green Building Design and Delivery, John Wiley \& Sons.

Kim, S., and B. E. Dale (2005) Environmental aspects of ethanol derived from non-tilled corn grain: non-renewable energy consumption and greenhouse gas emissions. Biomass \& Bioenergy 28: 475-489.

Kobayashi, H., H. Hagiwara, H. Kaneko, and Y. Ogami ( 2007) Effects of $\mathrm{CO}_{2}$ Dilution on Turbulent Premixed Flames at High Pressure and High Temperature. Proceedings of the Combustion Institute, 31, 1451-1458.

Li L. X., X.Q.Qiao, L.Zhang, J. H.Fang, Z.Huang, and H. M.Xia, (2005) Combustion and emission characteristics of a two-stroke diesel engine operating on alcohol, Renewable Energy30(132075-2084.

Lee, K.; Kim, T.; Cha, H.; Song, S.; Chun, K. M. (2010) Generating efficiency and NOx emissions of a gas engine generator fueled with a biogas-hydrogen blend and using an exhaust gas recirculation system. International Journal of Hydrogen Energy, Oxford, v. 35, n. 11, p. 5723-5730,

Mabee, W. E. (2007). Policy Options to Support Biofuel Production. Pages 329-357. Biofuels.

Michaelides , E.E. (2012) Alternative Energy Sources, Springer, London, NewYork.

Pankhaniya Milan, A., Bharatsinh Chauhan, B and SavanRanpara, C.( 2011) Study performance and exhaust analysis of petrol engine using Methanol-Gasoline blends. Institute of Technology, Nirma University, Ahmed Abad-382 481. Available on www.nuicone.org.pdf 
Sehsah, E.E. E.B. E.Belal, R.R.Abu shieshaa and A. Allawaty (2015) Bio-ethanol application as an alternative fuel in farm machine. Misr J. Ag. Eng. Vol. 13.No. (4) .3711-1290.

Solomon, B. D., (2007). Grain and cellulosic ethanol: History, economics, and energy policy. Biomass \& Bioenergy 31: 416-425.

Sun Q., H.Li, J.Yan, L.Liu, Z. Yu and X. Yu, (2015) Selection of appropriate biogas upgrading technology-a review of biogas cleaning, upgrading and utilization. Renewable and Sustainable Energy Reviews, Amsterdam, V. 51, p.521-532.

Yasar, A.; A. Ali, B. Tabinda and A. Tahir (2014) Waste to energy analysis of shakarganj sugar mills ; biogas production from the spent wash for electricity generation. Renewable and Sustainable Energy Reviews, Amsterdam, v. 43, n. 13, p. 126-132,.

Zhai H., H.C. Frey, N.M. Rouphail, G.A. Gonçalves and T.L. Farias (2007). "Fuel Consumption and Emissions Comparisons between Ethanol 85 and Gasoline Fuels for Flexible Fuel Vehicles," Paper No. 2007-AWMA-444, Proceedings, 100th Annual Meeting of the Air \& Waste Management Association, Pittsburgh, PA, June 26-28.

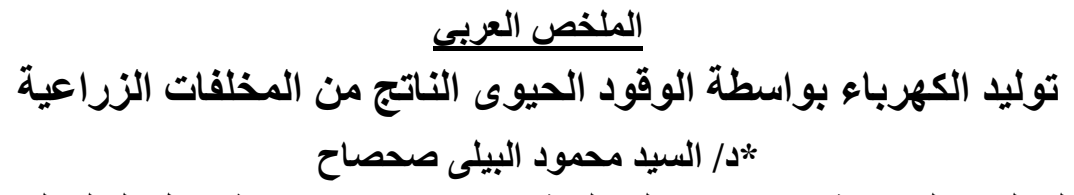

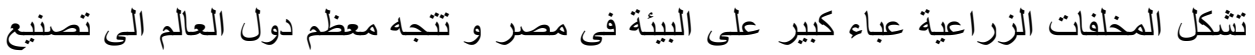

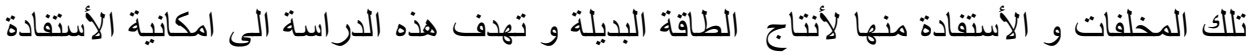

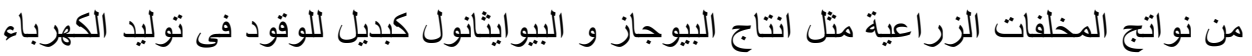

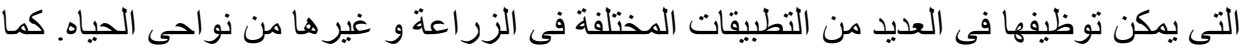

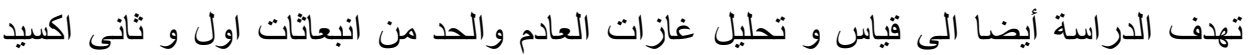

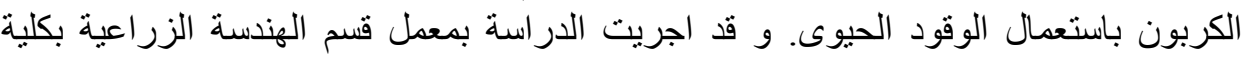

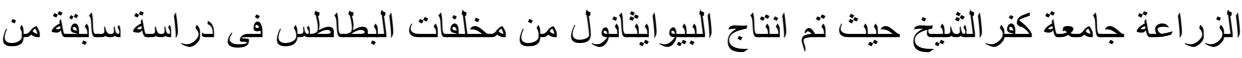

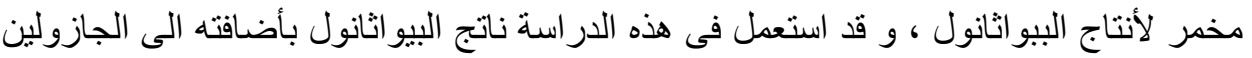

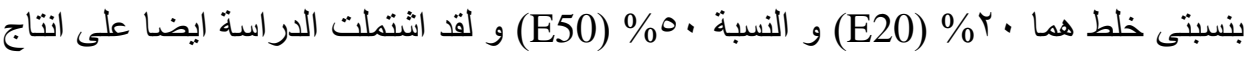

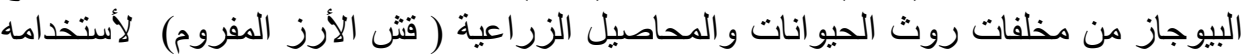

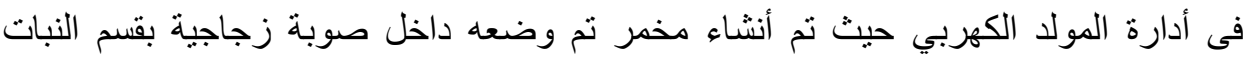

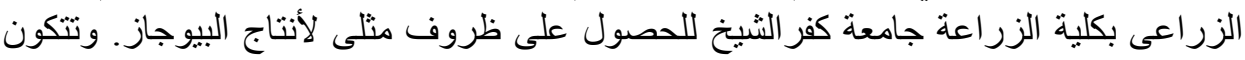

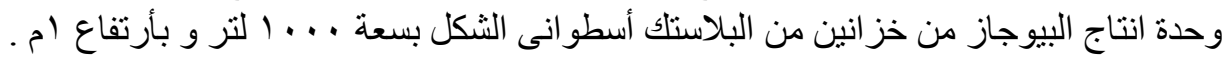

*أستاذ هندسة القوى و الالات المساعد-قسم الهندسة الزراعية ـ كلية الزراعةـ جامعة كفرالثيخ 
الخزان السفلى استعمل كمخمر بينما أستعمل الخزان العلوى بعد أز الة قمته لتجميع غاز البيوجاز

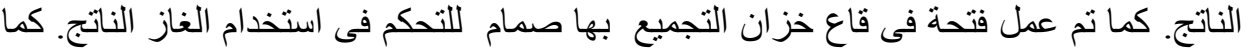

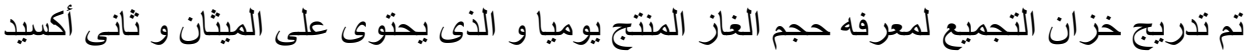

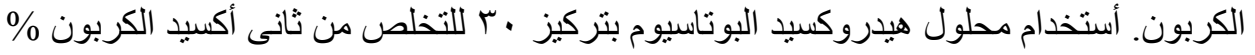

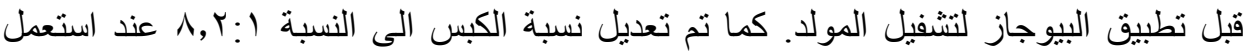

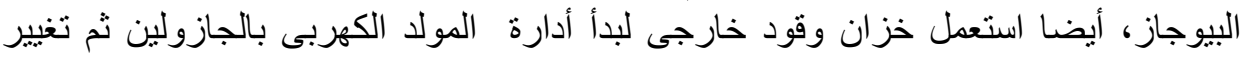

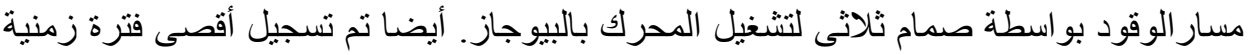

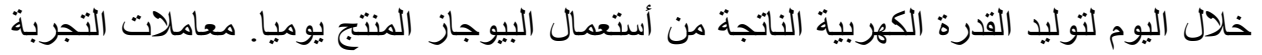

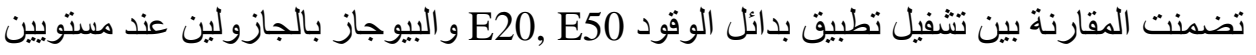

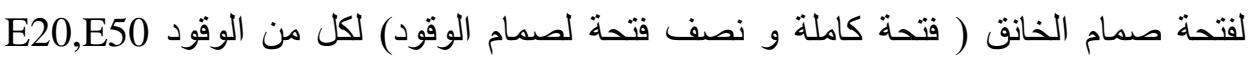

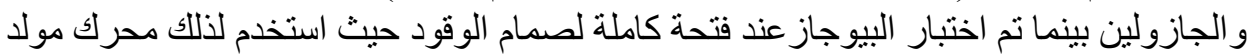

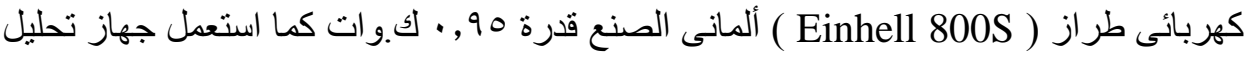

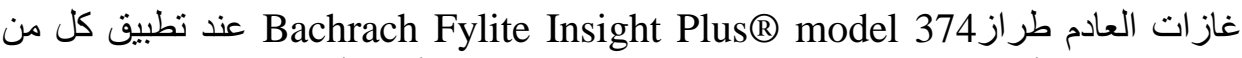
الجازولين رقم أوكتين •، و و الوقود الحيوى موضع الدراسة. أيضا أستخدمت طلمبة مياه قدرة

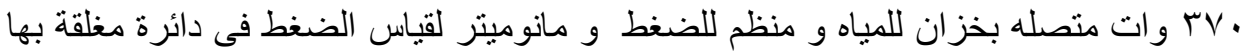

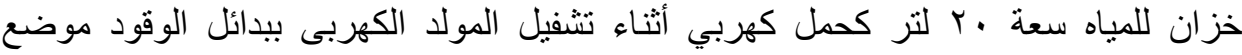

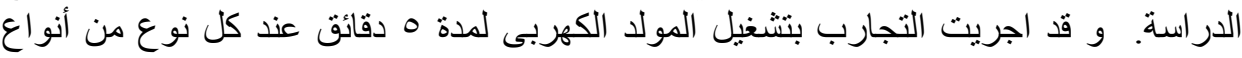

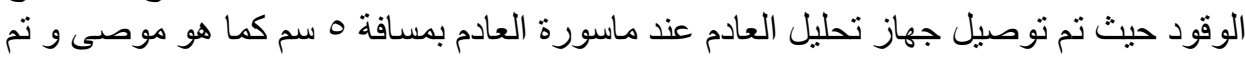
توصيل جهاز Multi-meter M346 بين المولد الكهربى و الحمل لقياس القدرة و و الطاقة

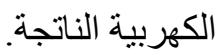
أهم النتائج المتحصل عليها: و قد تبين من النتائج أن أختبار الوقود الحيوى لكل من البيو ايثانول

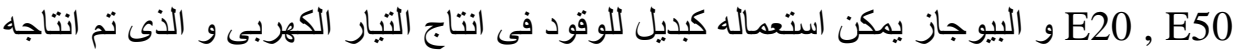

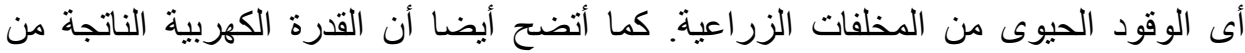

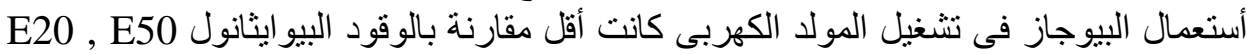

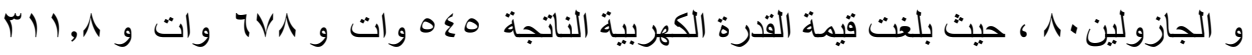

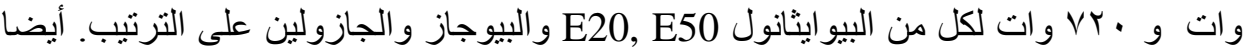

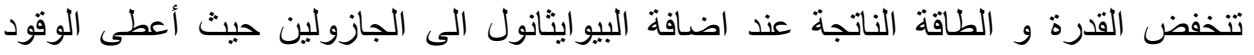

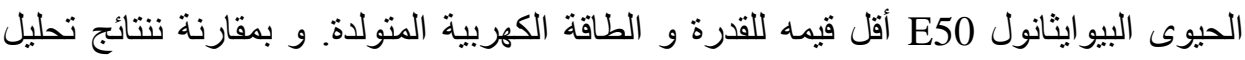

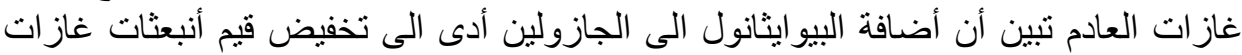

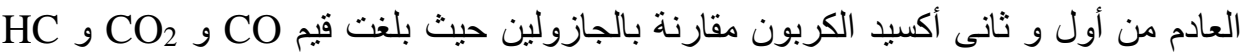

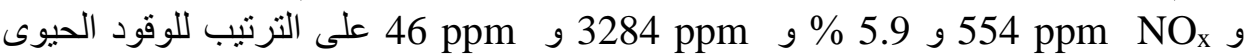

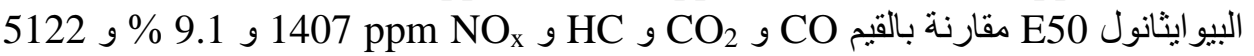

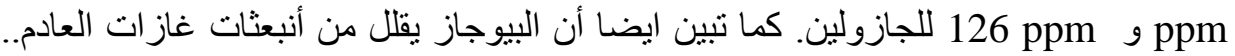

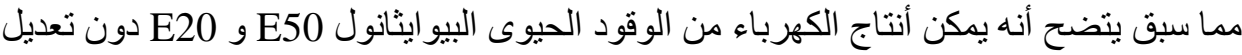

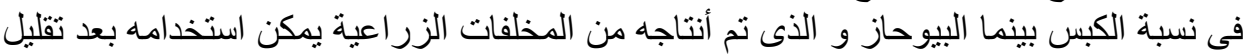

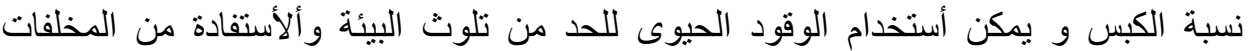
الزر اعية و الحد من أبعثات غاز ات العنام العادم. 